\title{
Feasibility and potential of separate anaerobic digestion of municipal sewage sludge fractions
}

\author{
Dilek Erdirencelebi' and Cansu Bayhan' \\ ${ }^{1}$ Environmental Engineering Department, Engineering and Natural Sciences Faculty, Konya Technical University, Konya 42250, Turkey
}

Feasibility of the separate anaerobic stabilization of primary (PS) and secondary (SS) sludge fractions produced in municipal wastewater treatment plants (WWTP) was studied at volatile loading rates (VLR) of 0.57-2.05 and $0.27-0.57 \mathrm{~kg} \mathrm{VS} /\left(\mathrm{m}^{3} \cdot \mathrm{d}\right)$ for PS and SS, respectively, corresponding to 16-30 and 14-28 d of hydraulic retention time (HRT). Laboratory-scale semi-continuous anaerobic reactors were operated at $35^{\circ} \mathrm{C}$. The operational performance and quality of the final stabilized sludge were monitored. PS and SS showed opposite thickening abilities exhibiting a need for direct feeding of PS to the digesters. Biodegradability was obtained as $52( \pm 1)$ and $40( \pm 5) \%$ volatile solid (VS) removal for PS and SS, respectively. Optimum VLR was determined according to the highest methane yield (specific methane production), VS reduction and dewaterability of the stabilised sludge. An inhibitory effect was observed at higher VLRs in PS digestion inducing a gradual reduction in the methane yield and daily production. High oil and grease content was subject to a substantial reduction in PS digestion showing a dependency on HRT. Conversely, a considerable degree of augmentation took place in the stabilised SS with no correlation to HRT at values lower than $30 \mathrm{~d}$. Efficient reduction in the oil and grease content improved dewaterability in stabilised PS whereas high oil and grease content prevented an improvement for stabilised SS. Major benefits were obtained as lower HRT and high stability with higher methane production and fertilizing ( $\mathrm{N}$ and $\mathrm{P}$ content) characteristics for digestion performance and stabilized SS, whereas direct feeding and higher HRT for PS digestion were determined as beneficial.

\section{INTRODUCTION}

An increasing trend in population and water usage induces a parallel increase in sewage sludge production in municipal wastewater treatment plants (WWTPs) (Mininni et al., 2015). Anaerobic sludge digestion is the most common stabilisation method for sludge volatile solids (VS) due to methane energy gain and a resulting final sludge quality with potential for use in soil remediation. Conventionally, primary (PS) and secondary sludge (SS) fractions are mixed, thickened and stabilized via anaerobic digestion as the most common methodology in municipal WWTPs. Each fraction possesses different contents and degree of biodegradability (Winter and Pierce, 2010). Settleable solids, mostly proteins and lipids, in the wastewater are separated into PS reaching a high dry and volatile solid (DS and VS) concentration (5-9\% DS (typical 6\%)) and transferred to the thickening unit where mixing with the SS is provided (Tchobanoglous et al., 2004). Conversion rate to methane is faster for PS due to raw organic matter content but SS has a lower DS and VS content (0.5-1.5\% DS (typical $0.8 \%$ DS)) composed of viable microorganisms and extracellular polymeric substances (EPS) for which hydrolysis rate is low. Hydrolysis becomes the rate-limiting stage of the anaerobic SS and mixed sludge (MS) digestion (Appels et al., 2008a). Mixing of SS and PS results in a lower solid content than PS alone in the thickened mixed sludge (MS) which can be observed in the gravity thickener results as $5-10 \%$ DS for PS thickening and $2-8 \%$ DS as PS+SS thickening (Tchobanoglous et al., 2004).

Efforts have been made to upgrade WWTP sludge line processes with improved anaerobic digestion efficiency under mesophilic and thermophilic conditions. Thermal hydrolysis and ultrasonication (UPT) have been commercialized and have been proven to cause a considerable increase in the VS removal and biomethanation of especially SS (Appels et al., 2008b, Cano et al., 2015). Novel techniques such as microwave irradiation and radiofrequency have emerged and have been shown to improve the digestion of sewage sludge and especially the SS fraction at bench-scale, but further investigation is needed to demonstrate self-sufficient economics at a larger scale (Kor-Bicakci and Eskicioglu, 2019).

Thermal pre-treatment (TPT) methods investigated by several researchers at a range of $60-220^{\circ} \mathrm{C}$ provided an increase in biogas production and VS degradation (Appels et al., 2008a). The aim of the first thermal hydrolysis applications was to enhance dewaterability prior to or after anaerobic digestion and was reached at temperatures greater than $150^{\circ} \mathrm{C}$ due to the release of bound water and intracellular water which required such elevated temperature application (Neyens and Baeyens, 2003; Pilli et al., 2015). High-temperature TPT was effective in the solubilization of protein (Bougrier et al., 2008; Mottet et al. 2009,Wilson and Novak, 2009) but reduced soluble carbohydrate content above $130^{\circ} \mathrm{C}$ (Bougrier et al., 2008; Mottet et al., 2009), adding to slowly biodegradable organic content with negligible effect on lipids (Muller, 2001; Bougrier et al., 2008). Consequently, TPT of SS proved more beneficial prior to mesophilic than thermophilic digestion at lab-scale, as the need to speed up of the mesophilic

\section{CORRESPONDENCE}

Dilek Erdirencelebi

EMAIL

derdirencelebi@ktun.edu.tr

\section{DATES}

Received: 05 February 2019

Accepted: 03 December 2019

\section{KEYWORDS}

sewage sludge

anaerobic

stabilization

primary

secondary

operation

methane

dewaterability

\section{COPYRIGHT}

(C) The Author(s)

Published under a Creative

Commons Attribution 4.0

International Licence

(CC BY 4.0) 
process is greater (Gavala et al., 2003). Cano et al. (2015) concluded that TS content was the main parameter in the self-sufficiency of the pre-treatment methods and full energy integration was required for TPT. Pre-thickening/dewatering of the raw sludge up to $15-16 \%$ dry solids (DS) by centrifuge was added to the method in all commercial applications necessitating a multi-stage and highly complex system (Pilli et al., 2015). Re-dilution and re-cooling of the pre-treated sludge is necessary before feeding to $\mathrm{AD}$ where different prethickening/dewatering procedures could be necessary for PS and SS, due to different water releasing characteristics, to reach the $15 \%$ DS level (Mehdizadeh et al., 2013). Thermal hydrolysis downstream of $\mathrm{AD}$ can improve dewaterability to a considerably higher degree and benefit for final incineration (Barber, 2016). Most of the TPT applications at full-scale were either implemented on SS alone or MS prior to incineration, for reduction in sludge volume, and thus the final disposal cost. Such upgrading of the WWTP sludge line has been popular in Europe due to land scarcity for landfilling (Barber, 2016). Separate treatment and disposal for PS and SS as wet oxidation of PS and TPT, followed by thermophilic anaerobic digestion for SS, with reference to a WWTP with incineration as the final disposal route resulted in $45 \%$ reduction of the sludge produced (Gianico et al., 2015). However, PS is highly amenable to anaerobic digestion, contributes to methane production, undergoes a high reduction in pathogen content and is a valuable energy source, able to provide $30 \%$ of WWTP energy consumption and thus sustainable wastewater management.

Modifications in the digestion technology at full-scale as conversion to a thermophilic level (Iranpour et al., 2002; Shao et al., 2002; Lloret et al., 2013) aimed to obtain higher methane recovery and class A biosolids where temperature-phased (thermophilic+mesophilic two-stage) anaerobic stabilization proved successful at overcoming the instability of single-stage thermophilic AD at lab-scale (Rubio-Loza and Noyola, 2010) and full-scale (Krugel et al., 2002; Windau, 2004). Thermophilic digestion, which is a high-rate process, and thus sensitive to changes in volatile loading rate (VLR), may exhibit insufficient stability compared to a mesophilic process; various data reported in the literature are inconsistent, leading to lack of confidence in one-stage thermophilic digestion at full-scale (Forster-Carneiro et al., 2010). A two-stage thermophilic+mesophilic AD system has high potential to overcome the drawbacks of the one-stage process, with an increase in biogas yield, stability, and final sludge quality, with lower final sludge volume, where a more complex system and operation are introduced compared with the current mesophilic system.

Pre-treatment methods have been proven to be mostly advantageous for SS, due to its low biodegradability, regarding economic gain, but can provide only a limited reduction of the total pathogen count entering the $\mathrm{AD}$ (as this amount is much higher in PS). MS or SS is pre-dewatered via centrifuge before TPT or UPT at full-scale applications, which necessitates polymer consumption, a re-dilution and re-cooling before feeding to AD (Pilli et al., 2015). All chemical cost figures, including pre- and final dewatering, need to be clarified regarding full-scale applications, where polymer consumption data is the missing information for determining pre-treatment technologies' cost efficiency, as it is only provided in varying patterns in a limited number of papers (Oosterhuis et al., 2014; Lancaster, 2015). The economics presented in the form of reduction in the digester retention time and volume, and increase in biogas, DS content and pasteurization degree, do not fulfil the net cost figures in all aspects including chemical costs, and may be the reason for the limited number of full-scale applications of pre-treatment technologies. Dissolved organic and ammonia nitrogen concentrations are very high in the stabilized sludge and supernatant (Dwyer et al., 2008). The organic end-products likely to exist in the final sludge are unknown and will change significantly depending on regional and local conditions. No data on the final total dissolved solids (TDS) or conductivity of the stabilized sludge, due to salinity being subject to increase through application of pre-treatment methods, were provided in the literature. The pre-treatment technologies are certainly advantageous in obtaining Class A biosolids in terms of pathogens, but this benefit may be cancelled out, for final use on land, due to increased ionic content, as VS removal and dissolved solids are increased by 4.5 and 10 times, respectively (Pilli et al., 2015). There is still a need to confirm the results obtained at lab-scale in the field, in terms of use of the stabilized sludge and supernatant for nutrient recovery, and remaining organic compounds and pathogens.

Sewage sludge characteristics varying regionally is another factor adding to the complexity of sludge stabilization. High solids loading (with pre-dewatering) will readily increase the biogas production, and the solids content of $\mathrm{AD}$ and outlet/ stabilized sludge. Methane production by anaerobic digestion can recover the energy consumption of the whole WWTP up to 75\% (Erdirencelebi and Kucukhemek, 2015), so, self-sufficiency of any pre-treatment method may not contribute to WWTP economics in terms of net energy gain, and thus may not be the optimum upgrade solution. The low VLR problem in AD feeding can be attributed to mixing of the PS and SS leading to weak thickening in the gravity thickeners and can be solved with pre-thickening/dewatering of the raw sludge by effective means (mechanical and/or chemical) (Tchobanoglous et al., 2004). For this aspect, separate thickening of PS and SS is a feasible solution. In fact, direct feeding of PS or reduced thickening retention time (for balancing the sludge flow) will eliminate the start of hydrolysis-acidification reactions, and thus biogas and odour formation, in this unit. Additionally, high retention time/ volume for $\mathrm{AD}$ is not a disadvantage as it will provide higher stability and sufficient time for effective hydrolysis and pathogen removal in PS.

Separate stabilization of PS and SS is a simpler approach in the upgrading of a WWTP sludge line, where dynamic thickening of SS will increase the VS loading, and thus methane recovery (Tomei et al., 2016). As a result, lower digestion time will be possible for SS digestion. Co-thickening of PS and SS fractions has important negative effects on WWTP operation as PS contains a high degree of VS and SS dilutes the VS content of the mixed sludge (MS) leading to lower density sludge feeding to ADs than the design value (Erdirencelebi et al., 2017). In that case, unsettled/unthickened solids are returned to the main line via recirculation of the thickener supernatant resulting in a vicious circle of solid matter between the primary settlers and the sludge thickeners (Erdirencelebi and Kucukhemek, 2015). Furthermore, solids escaping in the thickener supernatant to the main line increases the mixed liquor volatile suspended solid concentration (MLVSS) of the biological treatment unit, and reduces $\mathrm{F}: \mathrm{M}$ (food:microorganism) ratio, organic matter oxidation and nitrification levels due to excess VS loading. This situation creates a favourable condition for filamentous growth and dominance which may further lead to the deterioration of the major operational parameters of the biological treatment unit (e.g. reduced secondary settling performance, increase in effluent VSS concentration, bacterial washout and decrease in sludge age). Filamentous growth also affects $\mathrm{ADs}$ as the responsible bacteria are transported to ADs via wasted SS, which creates excessive scum causing interruption of $\mathrm{AD}$ automated feeding to the upper liquid/sludge level. Sludge that cannot be fed in 
these incidences returns to the main line and adds to the vicious circle of solids in the plant (Erdirencelebi and Kucukhemek, 2015). An optimum ratio determined for MS at 60(PS):40(SS) (v:v) by Pinto et al. (2016) is hardly possible to attain in a routine WWTP operation as PS is drawn on a periodical basis from the primary settling tanks during the daytime. Return SS is formed at varying solid content, depending on the settling degree in the secondary settling tanks, and pumped at varying flowrates to ensure the design biomass concentration and sludge age in the biological treatment unit.

In the current situation in Turkey, biogas production is emphasized and ADs in municipal WWTPs are operated at a constant hydraulic retention time (HRT) of 18-20 d, and need improvement for more efficient VS removal, higher biogas yield and higher final sludge quality via potential alternative operational systems. Separate stabilization of PS and SS is an alternative method to optimize anaerobic digestion of sewage sludge fractions (Winter and Pierce, 2010; Tomei et al., 2016). Both fractions have a comparable VS/total solids (TS) percentage but different biodegradability and dewatering characteristics as well as VS and pathogen contents. Separate stabilization has the potential to increase the stabilization degree and/or final sludge quality, and thus enable higher energy production and fewer operational problems.

The present study investigated the process feasibility of separate/ parallel anaerobic digestion of PS and SS fractions through assessing methane production, VS removal, $\mathrm{pH}$ and VFA level, total dissolved sulphide (TDS) production and stabilised sludge quality in terms of dewaterability, oil and grease, nitrogen $(\mathrm{N})$ and phosphate $(\mathrm{P})$ content. Long-term operational characteristics of the model were determined at increasing VLRs. Addition of $\mathrm{FeC}_{13}$ was implemented periodically to control possible TDSoriginating toxicity. Based on the results obtained, the feasibility and potential of the model are discussed and emerging criteria proposed for the sludge line.

\section{EXPERIMENTAL METHOD}

\section{Raw sludge characteristics}

PS was collected from the sludge outlet of the primary settling tanks and SS from the sludge return line in Konya municipal WWTP, having a 1.2 million population equivalence. One-litre sludge samples were subjected to Imhoff settling for 6 and $22 \mathrm{~h}$ (average thickening retention time) and their thickening ability was measured (2710 C - settled sludge volume (APHA, 2005)). The rest was stored at $+4^{\circ} \mathrm{C}$ during the study. Anaerobic inoculum was obtained from the outlet of the AD. The characteristics of the sludge samples in terms of $\mathrm{pH}$, total solids (TS), VS, oil and grease (\%TS) and dewaterability were determined as presented in Table 1. PS samples had a much higher solid, VS and oil and grease content than SS, and a lower $\mathrm{pH}$ level indicated that an anaerobic hydrolysis-acidification reaction had started. Time-to filter method $(2710 \mathrm{H})$ of Tests on Sludges (APHA, 2005) allow for comparison of the ability of sludge samples to release their water content, by determining the time necessary to filter half its initial volume. Lower filtering time represents better dewaterability, thus, lower dewatering chemical demand for stabilized sludge.

Table 1. Raw sludge sample characteristics

\begin{tabular}{lccccc}
\hline $\begin{array}{l}\text { Sludge } \\
\text { type }\end{array}$ & $\mathrm{pH}$ & $\begin{array}{c}\mathrm{TS} \\
(\mathrm{mg} / \mathrm{L})\end{array}$ & $\begin{array}{c}\mathrm{VS} \\
(\mathrm{mg} / \mathrm{L})\end{array}$ & $\begin{array}{c}\text { Oil and } \\
\text { grease } \\
(\% \mathrm{TS})\end{array}$ & $\begin{array}{c}\text { Time- } \\
\text { to-filter } \\
(\mathrm{mn})\end{array}$ \\
\hline $\mathrm{PS}$ & $6.3-7.0$ & $30000-50000$ & $25000-$ & $40-45$ & $5-10$ \\
SS & $7.2-8.0$ & $7000-11000$ & $4800-9000$ & $25-28$ & $1.67-2.5$ \\
Inoculum & $8.2-8.4$ & $17720-19000$ & $10900-12000$ & & \\
\hline
\end{tabular}

\section{Sequential batch reactor operation}

Batch reactors at $250 \mathrm{~mL}$ total volume with gas outlet were fed with PS, SS and MS prepared as $60 \%$ PS $+40 \%$ SS (v:v) in parallel mode for 5 -d periods. The reactors were set with $150 \mathrm{~mL}$ of inoculum sludge and received $50 \mathrm{~mL}$ of sewage sludge fraction followed by degasification (with $\mathrm{N}_{2}$ gas) and incubation at $35^{\circ} \mathrm{C}$. The mixing was provided by hand shake twice a day following the biogas measurement.

\section{Semi-continuous reactor operation}

Two $2000 \mathrm{~mL}$ glass (Schott) reactors with gas and sludge sampling outlets were operated in parallel and semicontinuous feeding/decanting mode with an active volume of $1500 \mathrm{~mL}$ at $35^{\circ} \mathrm{C}$. Sequential feeding of PS and SS were applied once a day depending on the hydraulic retention time (HRT). The volume fed was obtained by dividing the active volume by the HRT (1500 mL/HRT). The operation was conducted according to parameters given in Table 2 . The reactors were degasified (with $\mathrm{N}_{2}$ gas) and incubated at $35^{\circ} \mathrm{C}$ following the feeding. Mixing was provided by hand shake 3 times a day after the feeding and methane measurement. Monitoring of the process performance parameters was conducted as described: methane measurement (3/d), $\mathrm{pH}$, VFA, bicarbonate, TS, and VS (2/week), oil and grease and dewaterability (monthly). Iron chloride addition $(50 \mathrm{mg} / \mathrm{L}$ ) was applied to control TDS concentration.

\section{Analytical methods}

All the analytical methods implemented are presented below:

- Methane production was measured by liquid $(0.1 \mathrm{~N} \mathrm{NaOH})$ displacement method 3 times a day. Methane yield was calculated by dividing the daily methane production (L) by the amount of $\mathrm{VS}_{\text {fed }}(\mathrm{g})$ calculated by multiplying the feeding volume and VLR. VS $\mathrm{S}_{\text {fed }}$ represents the mass of the sludge fed in terms of volatile solids on a daily basis.

- Standard methods conducted for raw sludge samples were TS (2540.B), VS (2540.E), 2710 C - settled sludge volume and time-to filter method $(2710 \mathrm{H})$ (APHA, 2005).

- Standard methods conducted for stabilized sludge samples were TS (2540.B), VS (2540.E), TDS (4500 S ${ }^{2-}$ F iodometric method), oil and grease (g/g VS $\times 100)$ (5520.E.soxhlet extraction) and time-to-filter (2710 H) (APHA, 2005).

- $\mathrm{pH}$ of the sludge samples was measured by Hach Lange HQ40d Multi parameter instrument.

- Bicarbonate and VFA concentrations of the sludge samples were determined by a two-point titrimetric method according to Anderson and Young (1992).

Table 2. Semi-continuous reactor operating programme

\begin{tabular}{lccc}
\hline Sludge type & $\begin{array}{c}\text { HRT } \\
(\mathbf{d})\end{array}$ & $\begin{array}{c}\text { VLR } \\
\left(\mathrm{kg} \mathrm{VS} /\left(\mathrm{m}^{3} \cdot \mathrm{d}\right)\right.\end{array}$ & $\begin{array}{c}\text { Duration } \\
(\mathbf{d})\end{array}$ \\
\hline PS & 30 & 1.16 & 30 \\
& 25 & 1.3 & 30 \\
& 22 & 1.5 & 23 \\
& 20 & 1.64 & 21 \\
& 16 & 2.06 & 16 \\
\hline SS & 28 & 0.3 & 30 \\
& 24 & 0.33 & 25 \\
& 20 & 0.4 & 20 \\
& 18 & 0.44 & 18 \\
& 14 & 0.57 & 15 \\
\hline
\end{tabular}


- Total nitrogen $(\mathrm{TN})$ in the sludge samples was determined via Koroleff digestion with peroxodisulfate and photometric measurement with 2,6 dimethylphenol (Hach Lange LCK 338).

- Total phosphate (TN) was measured via phosphormolybdenum blue method (Hach Lange LCK 350).

\section{RESULTS}

An anaerobic digestion study was started with a preliminary batch stabilisation of PS, SS and MS. Results obtained on biogas production were evaluated and the study was continued with higher volume reactors at semi-continuous mode with PS and SS and increasing VLRs. The process performance and final stabilised sludge quality were determined for the separate digestion system.

PS and SS samples were first subjected to thickening which was only obtained for SS at $450 \mathrm{~mL} / \mathrm{L}$ at the end of $22 \mathrm{~h}$, whereas PS floated to the top $(700 \mathrm{~mL} / \mathrm{L})$ as a result of inner gas production. In the current practice, sludge thickeners are operated at $18-24 \mathrm{~h}$ HRT according to WWTP design criteria. The opposite behaviour of the two sewage sludge fractions in the thickening unit was the first result supporting the necessity of separate thickening or at least direct feeding of PS to the digesters. The design criteria range for thickening units is very large, at $2-8 \%$ dry solids (DS) (4\% typical) (Tchobanoglous et al., 2004). Gravity thickening of PS does not usually produce a higher solid percentage (5-10\% dry solids) than raw PS (5-9\% dry solids), possibly due to its floating behaviour which is a natural outcome of anaerobic degradation of sewage solids, consisting of mostly raw organic compounds in the form of proteins, lipids, carbohydrates and bacteria, during their transport in long sewage pipes and this can be observed by the blackish colour, sulphurous odour and gas production of PS solids. Sulphide production is a strong indicator of anaerobic hydrolysis of proteinaceous matter (Adams et al., 2007). Additionally, PS solid concentration is sufficiently high for feeding to ADs. Dewaterability (filtering ability) of the PS, SS and stabilised sludge fractions supported the findings of Erdirencelebi et al. (2017), being placed in descending order as follows: SS > stabilised sludge $>$ PS

\section{Batch study results}

The highest cumulative biogas production was obtained with PS digestion, but biogas yield in the fed VS base was higher for SS (Fig. 1a-b). Activity loss in the SS digestion occurred in the subsequent operation periods necessitating a change in the inoculum. Biogas production in MS digestion was obtained at a range between PS and SS at the lowest yield and underwent an activity loss where a new start with a new inoculum was necessary to increase its performance. Biogas yield obtained at $0.77 \mathrm{~L} / \mathrm{g} \mathrm{VS}_{\text {fed }}$ in the first periods dropped to $0.45 \mathrm{~L} / \mathrm{g} \mathrm{VS}_{\text {fed }}$ in PS digestion, whereas higher levels $\left(0.6-1.95 \mathrm{~L} / \mathrm{g} \mathrm{VS}_{\text {fed }}\right)$ were obtained for SS (Fig. 1b). According to the results, activity loss for SS digestion can be correlated to limited hydrolysis, and thus substrate+nutrient deficiency leading to starvation of anaerobic bacteria. Lower biodegradability of SS was reported in several studies (Krugel et al., 2002; Forster-Carneiro et al., 2010). Higher rates of VS loading might be a beneficial strategy to promote the methane production rate, whereas investigation of the final sludge quality in terms of dewaterability is useful towards achieving lower chemical/ polymer consumption in the decanter unit.

\section{Semi-continuous reactor study}

\section{Methane production, yield and TDS}

Different patterns were obtained for PS and SS in methane yield with increasing VLR (Fig. 2a). PS digestion showed a decreasing yield after reaching a maximum level of $800( \pm 20) \mathrm{mL} / \mathrm{g} \mathrm{VS}_{\text {fed }}$ at

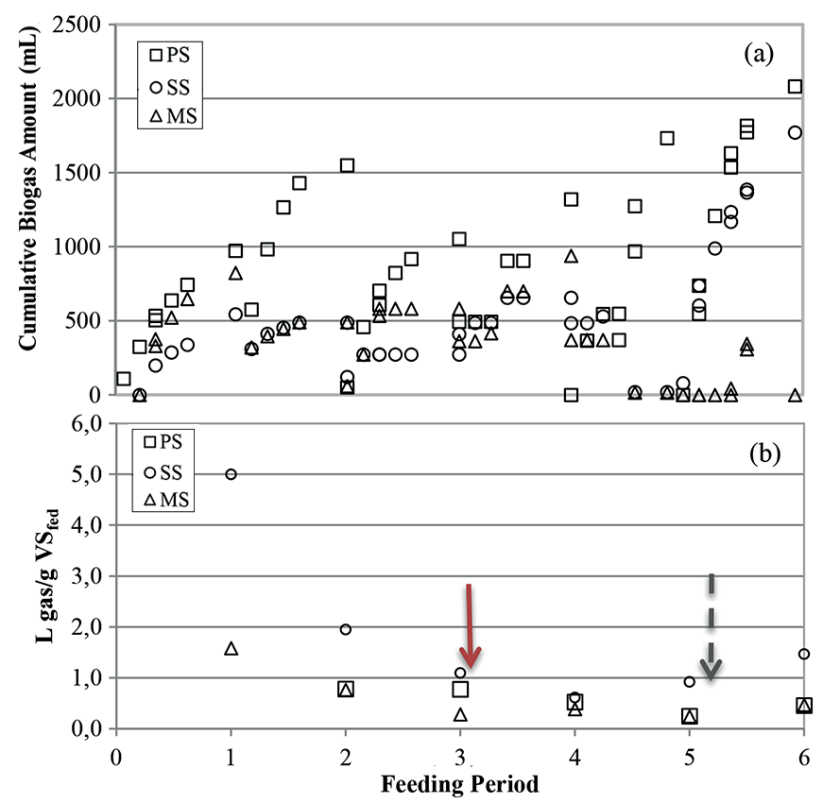

Figure 1. Sequential batch biogas production (a) and biogas yield (b) for PS, SS and MS (solid arrow: SS inoculum change; dotted arrow: MS inoculum change)
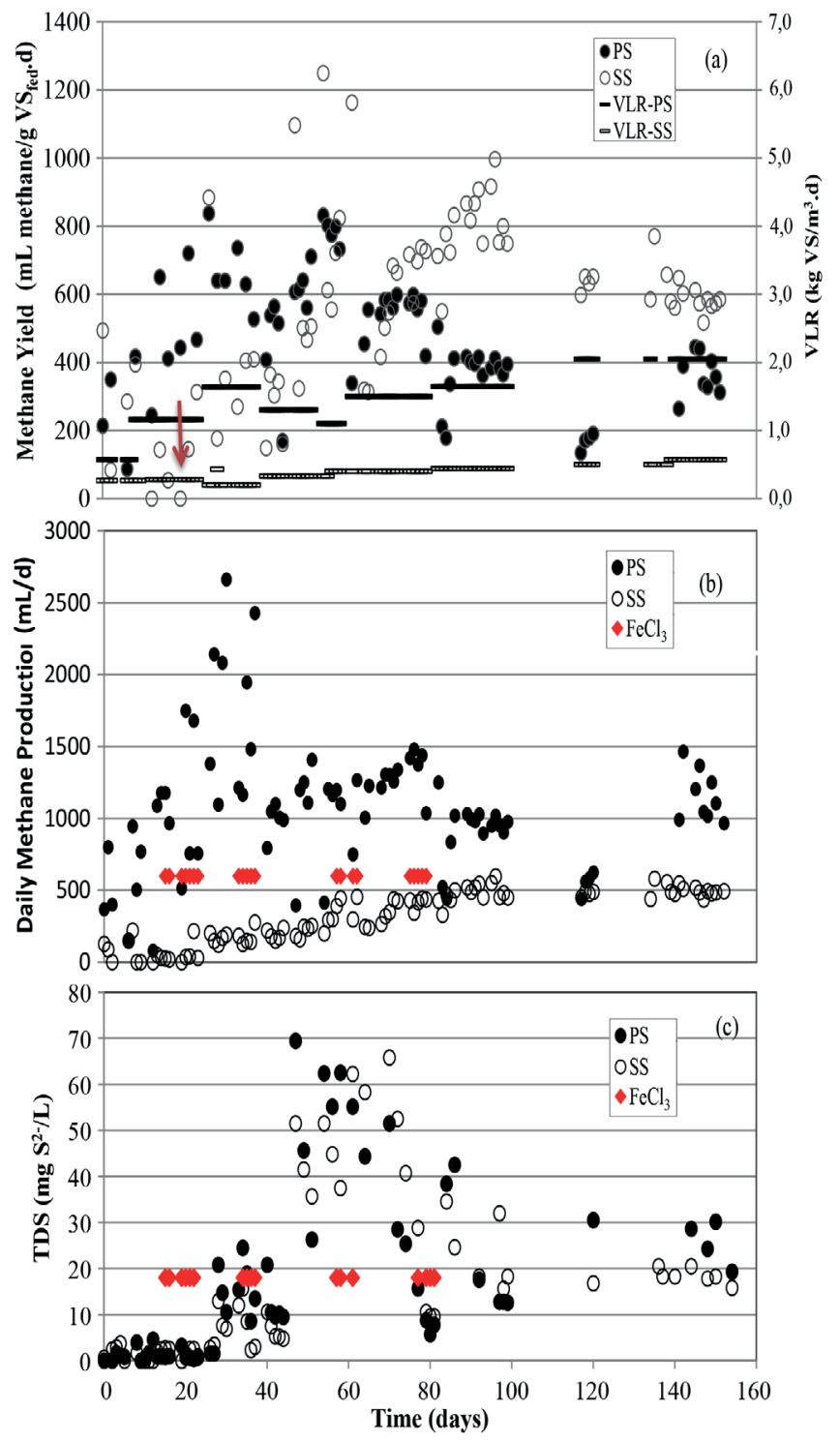

Figure 2 (a) Methane yield, (b) daily methane production, and (c) TDS concentration in the reactors (red arrow: SS inoculum change) 
$1.1 \mathrm{~kg} \mathrm{VS} /\left(\mathrm{m}^{3} \cdot \mathrm{d}\right)$, going down to stable levels of $580( \pm 20)$ and $400( \pm 15) \mathrm{mL} / \mathrm{g} \mathrm{VS}_{\text {fed }}$ at 1.5 and $1.65 \mathrm{~kg} \mathrm{VS} /\left(\mathrm{m}^{3} \cdot \mathrm{d}\right)$. This pattern supported the need for high HRT for PS at 25-30 d.

New inoculum addition to the SS digester was necessary due to activity loss; activity was recovered and yield increased up to $835( \pm 75) \mathrm{mL} / \mathrm{g} \mathrm{VS}_{\text {fed }}$ with increasing VLR to $1.44 \mathrm{~kg} \mathrm{VS} /\left(\mathrm{m}^{3} \cdot \mathrm{d}\right)$. The yield value was highly stable even when it dropped at higher VLRs. Results indicated that optimum HRT was $18 \mathrm{~d}$ for maximum methane yield in SS digestion, able to produce $600( \pm 30) \mathrm{mL} / \mathrm{g} \mathrm{VS}_{\text {fed }}$ at a lower HRT of $14 \mathrm{~d}$ with a stable pattern.

Daily methane production proceeded at the highest but fluctuating level of $1200-2200 \mathrm{~mL} / \mathrm{d}$ at $1.64 \mathrm{~kg} \mathrm{VS} /\left(\mathrm{m}^{3} \cdot \mathrm{d}\right) \mathrm{VLR}$ for PS (Fig. 1b). VLR was reduced successively to $1.3,1.1$ and raised to $1.5 \mathrm{~kg} \mathrm{VS} /\left(\mathrm{m}^{3} \cdot \mathrm{d}\right)$ in order to establish stability in the digester. A stable level of $1350( \pm 40) \mathrm{mL} \mathrm{CH}_{4} / \mathrm{d}$ was reached during this period. The subsequent VLR increase to $1.65 \mathrm{~kg} \mathrm{VS} /\left(\mathrm{m}^{3} \cdot \mathrm{d}\right)$ initiated a deterioration in the daily methane production as a significant drop to $1000( \pm 40) \mathrm{mL} \mathrm{CH}_{4} / \mathrm{d}$ took place. This decrease pointed to an accumulating inhibitor effect as stable and constant methane production would be expected if the hydrolysis rate was exceeded. An increase in methane production at the highest VLR $\left(2.05 \mathrm{~kg} \mathrm{VS} /\left(\mathrm{m}^{3} \cdot \mathrm{d}\right)\right)$ where new raw sludge was used supports the existence of a previous source-originating inhibitory effect.

In SS digestion, daily methane production reached its highest level of $500( \pm 50) \mathrm{mL} \mathrm{CH}_{4} / \mathrm{d}$ at $0.44 \mathrm{~kg} \mathrm{VS} /\left(\mathrm{m}^{3} \cdot \mathrm{d}\right)$ and no further change was obtained at $0.57 \mathrm{~kg} \mathrm{VS} /\left(\mathrm{m}^{3} \cdot \mathrm{d}\right) \mathrm{VLR}$, indicating that the hydrolysis rate was reached. The overall pattern was highly stable compared to the PS digester.

Iron chloride addition did not exhibit a significant effect on both methane data and TDS concentration, which proceeded at similar levels in both digesters, reaching a maximum level of $60( \pm 5) \mathrm{mg} \mathrm{S}^{2-} / \mathrm{L}$ at VLRs of 1.3-1.5 (PS) and $0.33-0.4 \mathrm{~kg} \mathrm{VS} /\left(\mathrm{m}^{3} \cdot \mathrm{d}\right)(\mathrm{SS})$ and then dropped down to stable levels in the $15-32 \mathrm{mg} \mathrm{S}^{2-} / \mathrm{L}$ range. Production of sulphide species is a result of proteinaceous organic matter hydrolysis and the pattern may be assessed as a delayed effect of iron chloride addition. The fact that iron chloride addition did not
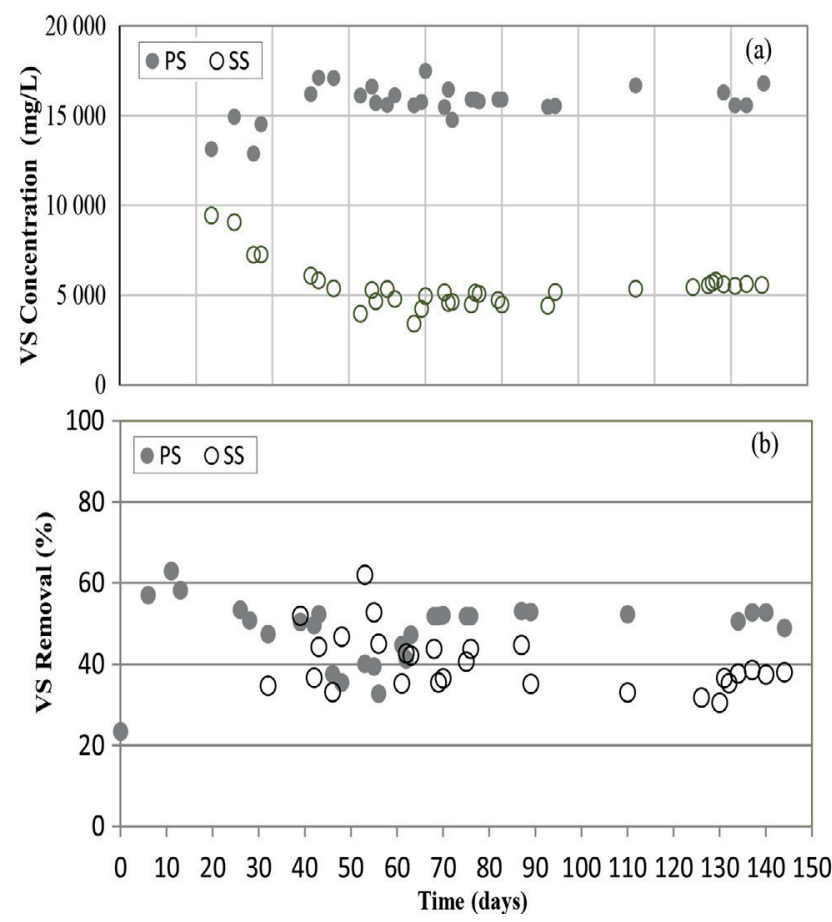

Figure 3. Effluent sludge(a) VS concentration and (b) \% VS removal produce a significant effect on methane production indicated that iron deficiency did not exist.

\section{VS content and removal}

VS concentration of the effluent/stabilized sludge and digester showed an opposite pattern for PS and SS digestion, respectively, as increasing and decreasing from the starting level (Fig. 3a). It ascended to around $16000 \mathrm{mg} \mathrm{VS} / \mathrm{L}$ (1.6\% VS) and stabilised at this level for stabilized PS, exhibiting no dependence on VLR and indicating that hydrolysis rate was not exceeded. Decreasing VS of the stabilized SS supported a deficiency of substrate and/ or nutrients due to limited hydrolysis as biomass stabilised at a much lower level $(4850( \pm 350) \mathrm{mg} \mathrm{VS} / \mathrm{L})$. A significant rise to $5600( \pm 50) \mathrm{mg} \mathrm{VS} / \mathrm{L}$ at the highest VLR indicated a hydrolysis rate between 0.44 and $0.57 \mathrm{~kg} \mathrm{VS} /\left(\mathrm{m}^{3} \cdot \mathrm{d}\right)$ for SS digestion, supported by a drop in VS removal to $37( \pm 2) \%$ at the highest VLR from $40( \pm 5) \%$ (Fig. 3b).

VS removal reached a stable $52 \%$ level in the PS digestion after Day 70 in $1.5 \mathrm{~kg} \mathrm{VS} /\left(\mathrm{m}^{3} \cdot \mathrm{d}\right) \mathrm{VLR}$ period and proceeded at that value at the highest VLR (Fig. 3b). Consistency in both VS concentration and removal degree supported that hydrolysis rate was not exceeded and this level showed the biodegradability degree of PS.

\section{Oil and grease}

Oil and grease content of the final/stabilised PS and SS are presented as percentage of TS in Fig. 4a. This was reduced to a range of $6-16 \%$ in PS digestion, with a substantial degree of $85-88,69-78$ and $65-72 \%$ removal at HRT of 30,25 and $16-22 \mathrm{~d}$, respectively. Oil and grease content was very high in the raw PS and a significant effect of HRT/VLR was determined, indicating a high-HRT advantage in reducing the lipid content in the stabilised PS. An opposite pattern was obtained in SS digestion as an increase in the oil and grease content up to $35-40 \%$ occurred at HRT values $<30 \mathrm{~d}$ in stabilised SS samples. A low degree of removal, at $6-19 \%$, was cancelled out within the reduction in VS and TS. This was correlated to the low biodegradability of bacterial cells in SS which retained their cellular lipids and transported them into the stabilised sludge.
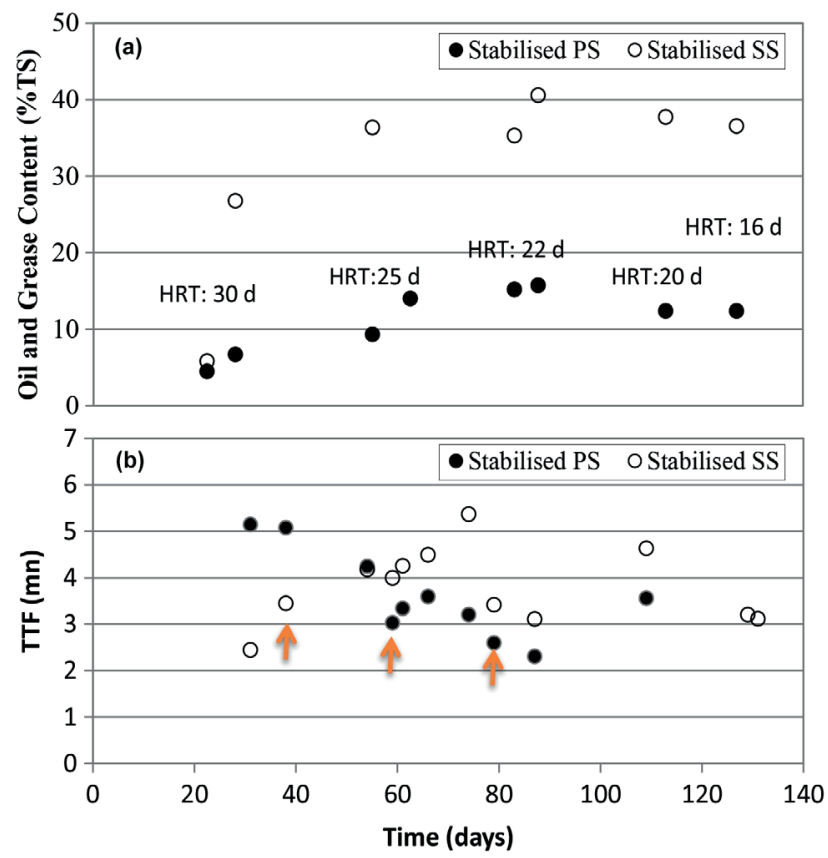

Figure 4. (a) Oil and grease content, and (b) dewaterability of the stabilised PS and SS (orange arrow: iron chloride addition) 


\section{Dewaterability}

Dewaterability determined as time-to-filter (filtering time) values obtained for stabilised sludge fractions showed opposite levels for PS and SS in the earliest period, as high and low, respectively, corresponding to VLRs of 1.64 and $0.3 \mathrm{~kg} \mathrm{VS} /\left(\mathrm{m}^{3} \cdot \mathrm{d}\right)$ (Fig. 4b). The dewatering ability increased as the PS digester's stability improved, reaching a minimum value of less than half at the same VLR on Day 89, indicating that stable operation was an important factor. Iron chloride addition had some positive effect on filtering time.

Dewatering ability of the stabilised SS proceeded with a fluctuating pattern throughout the study with a limited improvement at the highest VLRs $\left(0.44\right.$ and $\left.0.57 \mathrm{~kg} \mathrm{VS} /\left(\mathrm{m}^{3} \cdot \mathrm{d}\right)\right)$ indicating that lower HRT, thus, lower destruction of SS, may require a lower chemical/polymer consumption at the decanter unit than lower VLRs/higher HRT. High oil and grease content is known to affect stabilised sludge dewaterability and beneficial usage in a negative direction (Ziels et al., 2016). Reduction in filtering time in stabilised PS to lower levels than stabilised SS was correlated to efficient removal of oil and grease. As oil and grease content increased in stabilised SS during digestion, its negative effect on dewaterability was observed, with higher and fluctuating filtration time values compared to stabilised PS.

\section{pH, HCO3- and VFA balance}

$\mathrm{pH}$ proceeded at stable levels of 7.85-8.55 and 7.99-8.75 in the stabilised PS and SS, respectively (Fig. 5a). Anaerobic digestion increased $\mathrm{pH}$ of both raw PS (6-6.45) and SS (7.05-7.3). The acidic $\mathrm{pH}$ of PS indicated that hydrolysis and acidification reactions had started within the raw sludge. VFA rising to slightly higher levels $\left(120-173 \mathrm{mg} \mathrm{CaCO}_{3} / \mathrm{L}\right)$, starting on Day 68 at $1.5 \mathrm{~kg} \mathrm{VS} /\left(\mathrm{m}^{3} \cdot \mathrm{d}\right)$, indicated a slightly toxic effect on the methanogenesis stage. Similarly, maximum VFA concentration in SS digestion occurred at a slightly higher level as 179-206 mg CaCO$/ \mathrm{L}$, indicating some stress for methanogens. The buffering compound of anaerobic digestion, bicarbonate,

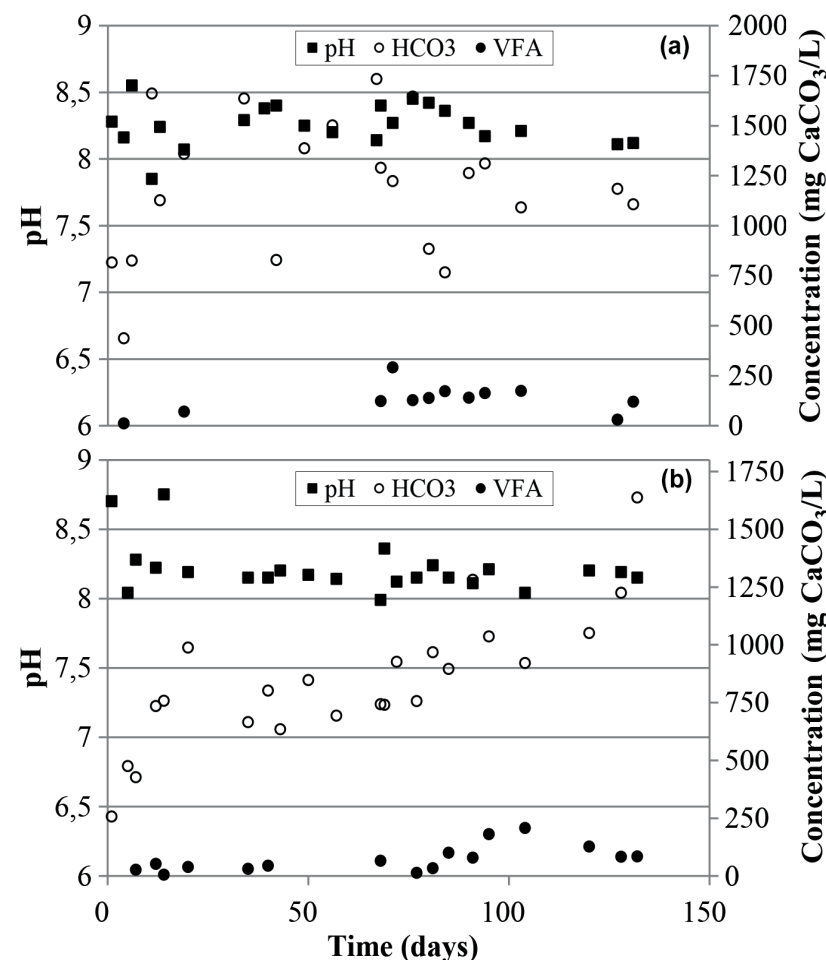

Figure 5. $\mathrm{pH}$, bicarbonate and VFA balance of (a) PS and (b) SS fed digesters tended to occur at a higher and larger range in the PS digestion, as $800-1700 \mathrm{mg} \mathrm{CaCO}_{3} / \mathrm{L}$ versus $600-1000 \mathrm{mg} \mathrm{CaCO} / \mathrm{L}$ for SS digestion. This was attributed to a higher degree of proteinaceous matter destruction in PS digestion. Higher acidification and VFA production in PS digestion were reported at a much lower lipid content of $6.4-14.8 \%$ by Gonzales et al. (2003).

\section{Nutrient content}

$\mathrm{N}$ content was determined as $56.5-84$ and $120-177 \mathrm{mg} \mathrm{N} / \mathrm{g}$ VS for stabilised PS and SS, respectively. Similarly, P content was lower for stabilised PS; $12-20 \mathrm{mg} \mathrm{P/g}$ VS versus 30-56 mg P/g VS for stabilised SS. Yan et al. (2013) obtained similar ranges for $\mathrm{N}$ and P content as 65.9-90 mg N/g VS and 15-27 mg P/g VS for stabilised PS versus $130-187.5 \mathrm{mg} \mathrm{N} / \mathrm{g}$ VS and $25.6-60 \mathrm{mg} \mathrm{P} / \mathrm{g}$ VS for stabilised SS.

\section{DISCUSSION}

A model of separate anaerobic digestion was studied and different degrees of biodegradability were obtained as $52( \pm 1)$ and $40( \pm 5) \%$ VS removal for PS and SS, respectively. High removal and methane yield levels according to literature were correlated to high oil and grease content (Tchobanoglous et al., 2004) and a related toxic effect was observed as a consequence. The best operational parameters were determined to guide full-scale application, both in terms of energy gain and chemical savings.

Optimum VLRs were obtained for long-term operation resulting in different HRTs for sewage sludge fractions. For PS digestion, $1.3 \mathrm{~kg} \mathrm{VS} /\left(\mathrm{m}^{3} \cdot \mathrm{d}\right)$ resulted in the highest methane yield whereas $1.5 \mathrm{~kg} \mathrm{VS} /\left(\mathrm{m}^{3} \cdot \mathrm{d}\right)$ provided VS removal at the highest level $(52 \%)$ and a better dewatering ability for the final/stabilised sludge. The corresponding HRT range was obtained at 22-25d for an average VS content of $33000 \mathrm{mg} / \mathrm{L}$ for raw PS. High HRT proved a better strategy for PS digestion to obtain higher methane yield and VS removal where stable long-term operation was an important factor for dewaterability.

For SS digestion a highly stable performance was obtained during the study. $0.44 \mathrm{~kg} \mathrm{VS} /\left(\mathrm{m}^{3} \cdot \mathrm{d}\right)$ VLR and an HRT of $18 \mathrm{~d}$ resulted in the highest methane yield and dewatering ability, whereas highest VLR $\left(0.57 \mathrm{~kg} \mathrm{VS} /\left(\mathrm{m}^{3} \cdot \mathrm{d}\right)\right)$ and lowest HRT $(14 \mathrm{~d})$ values proved feasible in the study as comparable performance was obtained. Maximum hydrolysis rate for VS was estimated as a value between these VLRs $\left(0.44-0.57 \mathrm{~kg} \mathrm{VS} /\left(\mathrm{m}^{3} \cdot \mathrm{d}\right)\right)$. Highrate SS digestion, depending on VS removal not exceeding the hydrolysis rate, is possible for optimum dewaterability of the waste biological sludge, which will lower chemical cost at the decanter unit due to limited degradation. High nutrient content is an advantage for use on land, but the exceptionally high oil and grease content encountered was due to local conditions and may cause a disadvantage. Lower levels of oil and grease content of stabilized SS were reported even for raw PS (Tchobanoglous et al., 2004; Gonzales et al., 2003). Local source-based control of this pollutant would be a solution or pre-treatment technologies effective in bacterial cell destruction would ease its hydrolysis and conversion to methane. Wouter and Verstraete (1997) obtained a lower methane yield at $0.52-0.6 \mathrm{~L} / \mathrm{g} \mathrm{VS}_{\text {fed }}$ and VS removal $(35 \%)$ at much higher $\operatorname{VLR}\left(0.6-0.79 \mathrm{~kg} \mathrm{VS} /\left(\mathrm{m}^{3} \cdot \mathrm{d}\right)\right)$ in PS digestion. Kepp and Solheim (2000) reported much lower methane yield ranges as 306 and $146-217 \mathrm{~L} / \mathrm{kg}$ for PS and SS, respectively. Methane yield obtained was similar for SS digestion at higher VLRs $\left(0.2-0.99 \mathrm{~kg} \mathrm{VS} /\left(\mathrm{m}^{3} \cdot \mathrm{d}\right)\right)$ by Martinez et al. (2016). Higher loading at the same retention and methane production levels led to lower VS removal.

HRT of $18-20 \mathrm{~d}$ for anaerobic MS digestion in Turkey enables high methane production rates but leads to lower DS content in 
the final dewatered sludge and VS degradation. Foam originating from filamentous bacteria is experienced in all the digesters of the WWTP. These drawbacks can be solved with separate sludge digestion with/without a convenient pre-treatment, where lower HRT for SS digestion can produce higher methane levels, at lower reactor volumes, and chemical cost and with higher fertilizer quality of the stabilised sludge as well as lower pathogen level and easier control of foaming in the digester. Winter and Pearce (2010) proposed separate digestion of SS and agricultural use due to its rich nutrient content. Separate anaerobic digestion under $\mathrm{pH}$ control proceeded via totally different mechanisms and provided a higher VS removal for SS (Gomec and Speece, 2003). The present study showed that methane yield can approach values for PS digestion at high VLRs. Lower values and higher HRT tend to disintegrate SS structure and reduce its dewaterability degree (Carrere et al., 2010; Erdirencelebi et al., 2017). TPT for SS can augment methane production, VS removal and sludge volume reduction but will increase dissolved solids (salinity) in the stabilized sludge and chemical/polymer costs, requiring a highly complex system for which further data are necessary at full-scale (Barber, 2016). Pre-treatment via chemical or physical means may result in a greatly destroyed bacterial and floc structure, and a higher methane yield, but much reduced dewaterability.

High VLRs may present risks for PS digestion as many toxic pollutants tend to accumulate, to a large degree adsorbed on the raw particulate matter (e.g. heavy metals, lipid matter, toxic organics). Gianico et al. (2015) proposed wet aerobic oxidation for PS as advantageous versus incineration or landfilling. VS content and methane recovery from PS is high and contributes to overall WWTP operational costs at a considerably higher level than SS; therefore, another stabilisation method as an alternative to anaerobic digestion will bring multiple costs to WWTP operation. Additionally, an important contribution can be made by mechanical thickeners to the degree of thickening of SS (Mininni et al., 2015; Tomei et al., 2016). SS thickening/ dewaterability degree depends on several factors and nutrientremoving modified activated sludge systems on the main line can produce SS with high settling ability (Erdirencelebi and Kucukhemek, 2015).

Higher retention times for PS digestion in the separate system compared to current practice will provide better VS removal and maintain high methane recovery rates, enabling elimination of sludge thickeners which can significantly reduce floating solids recycle to the main line treatment units.

The results still need to be adjusted in continuously fed digesters as continuous stirring and feeding can result in different parametric values and possibly higher VLRs. Change in PS character is another drawback of the proposed model where introduction of industrial wastewaters to domestic sewers is an important risk for stable methanogenic performance as potential toxicants may cause deterioration of the process. Within the study period, some inhibitory effect was obtained and optimum VLR was determined accordingly. Higher rates may be possible in WWTPs receiving only domestic wastewaters.

\section{CONCLUSIONS}

The separate sewage sludge digestion study for municipal WWTP sludge stabilisation concluded that:

- Different degrees of biodegradability were obtained as 52(+/-1) and $40(+/-5) \%$ VS removal for PS and SS, respectively, in the separate anaerobic digestion model.

- Lower HRT proved applicable for SS digestion at a high stability and nutrient content in the stabilised sludge.
- Feasibility was shown for PS digestion as higher HRT, methane yield, improved dewaterability and direct feeding to the digesters, offering a high potential with some risks. A lab- or pilot-scale feasibility study is necessary to determine the optimum VLR before real-scale implementation. Higher VLRs than hydrolysis rate will lead to VS and possible inhibitor accumulation in the digester.

- Oil and grease proved an important parameter in the anaerobic digestion of sewage sludge, affecting both methane yield and dewatering ability. High oil and grease content in PS was effectively converted to methane and dewaterability was improved, whereas limited destruction of bacterial cells allowed a low degree of removal of the reserved cellular content and resulted in an augmentation in the stabilised SS.

\section{ACKNOWLEDGMENTS}

The work was financed by BAP Coordinate of Selcuk University (SU) in the scope of 17201112 numbered graduate thesis project. The authors thank SU BAP Coordinate for the financial support and Konya Water and Sewage Administration's Wastewater Branch for the provision of sludge samples. The authors thank to Hamza Aysan for valuable support in the reactors' operation and analyses.

\section{GLOSSARY}

Dewaterability: The ability of the sludge to release its water content.

Time-to-filter: Time necessary to filter half the initial sludge sample volume representing the ability to release its water content. The lower the time value, the higher is the dewatering ability.

HRT: Hydraulic retention time of the anaerobic stabilization gives the reactor volume necessary for a given sludge flow rate. Lower HRT means lower reactor volume.

VLR: Volatile loading rate represents the VS entering the AD per $\mathrm{m}^{3}$ of its volume on a daily basis. If sludge feeding/flow rate is increased, VLR is increased and HRT is reduced on the AD.

Methane yield: Specific methane production per sludge VS loading in $\mathrm{m}^{3} /(\mathrm{kg} \mathrm{VS} \cdot \mathrm{d})$.

\section{REFERENCES}

ADAMS GM, WITHERSPOON JR, ERDAL ZK, FORBES RH, HARGREAVES JR, HIGGINS MJ, MCEWEN DW and NOVAK JT (2007) Identifying and controlling the municipal wastewater odor environment Phase 3: Biosolids processing modifications for cake odor reduction. Water Environment Research Foundation, Report No.03-CTS-9T. WERF, Alexandria VA, USA.

ANDERSON GK and YANG G (1992) Determination of bicarbonate and total volatile acid concentration in anaerobic digesters using a simple titration. Water Environ. Res. 64 (1) 53-59. https://doi. org/10.2175/WER.64.1.8

APHA (2005) Standard Methods for the Examination of Water and Wastewater. American Public Health Association, AWWA and WEF, Washington DC.

APPELS L, BAEYENS J, DEGREVE J and DEWIL R (2008a) Principles and potential of the anaerobic digestion of waste-activated sludge. Progress Energ. Combust. Sci. 34 755-781. https://doi.org/10.1016/j. pecs.2008.06.002

APPELS L, DEWIL R and BAEYENS J (2008b) Ultrasonically enhanced anaerobic digestion of waste activated sludge. Int. J. Sustainable Energ. 1 (2) 94-104. https://doi.org/10.1080/19397030802243319

BARBER WPF (2016) Thermal hydrolysis for sewage treatment: A critical review. Water Res. 104 53-71. https://doi.org/10.1016/j. watres.2016.07.069

BOUGRIER C, DELGENES JP and CARRERE H (2008) Effects of thermal treatments on five different waste ctivated sludge samples 
solubilisation, physical properties and anaerobic digestion. Chem. Eng. J. 139 (2) 236-244. https://doi.org/10.1016/j.cej.2007.07.099

CANO R, PEREZ-ELVIRA SI and FDZ-POLANCO F (2015) Energy feasibility study of sludge pretreatments: A review. Appl. Energ. 149 176-185. https://doi.org/10.1016/j.apenergy.2015.03.132

CARRERE H, DUMASC, BATTIMELLI A, BATSTONE DJ, DELGENES JP, STEYER JP and FERRER I (2010) Pretreatment methods to improve sludge anaerobic degradability: a review. J. Hazardous Mater. 183 (1-3) 1-15. https://doi.org/10.1016/j.jhazmat.2010.06.129

DWYER J, STARRENBURG D, TAIT S, BARR K, BATSTONE DJ and LANT P (2008) Decreasing activated sludge thermal hydrolysis temperature reduces product colour, without decreasing degradability. Water Res. 42 (18) 4699-4709. https://doi.org/10.1016/j. watres.2008.08.019

ERDIRENCELEBI D, SARIKAYA F, BAYHAN C and AYSAN H (2017) Anaerobic biodegradability and dewaterability of sewage sludge fractions: potential for separate anaerobic stabilization in sequential batch reactors. In: Proceedings of the International Symposium on Environmental Science and Technology (2017 ISEST), 19-22 September 2017, Beijing.

ERDIRENCELEBI D and KUCUKHEMEK M (2015) Diagnosis of the anaerobic reject water effects on WWTP operational characteristics as a precursor of bulking and foaming. Water Sci. Technol. 71 (4) 572-579. https://doi.org/10.2166/wst.2014.528

FORSTER-CARNEIRO T, RIAU V and PEREZ M (2010) Mesophilic anaerobic digestion of sewage sludge to obtain Class B biosolids Microbiological methods development. Biomass Bioenerg. 34 18051812. https://doi.org/10.1016/j.biombioe.2010.07.010

GAVALA HN, YENAL U, SKIADAS IV, WESTERMANN $P$ and AHRING BK (2003) Mesophilic and thermophilic anaerobic digestion of primary and secondary sludge: Effect of pre-treatment at elevated temperature. Water Res. 37 4561-4572. https://doi. org/10.1016/S0043-1354(03)00401-9

GIANICO A, BERTANZA G, BRAGUGLIA CM, CANATO M, LAERA G, HEIMERSSON S, SVANSTRÖM M and MININNI G (2015) Upgrading a wastewater treatment plant with thermophilic digestion of thermally pre-treated secondary sludge: techno-economic and environmental assessment. J. Clean. Prod. 102 353-361. https://doi. org/10.1016/j.jclepro.2015.04.051

GOMEC CY and SPEECE R (2003) Organic material solubilization of domestic primary sludge in anaerobic digestion at controlled pH. Water Sci. Technol. 48 (4) 195-198. https://doi.org/10.2166/ wst. 2003.0253

GONZALES M, ASSADI M and OUKI S (2003) Effect of sludge composition on the degree of stabilisation and gas production during mesophilic anaerobic digestion (MAD). Proceedings of the 8th European Biosolids and Organic Residuals Conference, 24-26 November 2003, Wakefield.

IRANPOUR R, COX HHJ, SHAO YJ, MOGHADDAM O, KEARNEY RJ, DESHUSSES MA, STENSTROM MK and AHRING BK (2002) Changing mesophilic wastewater sludge digestion into thermophilic operation at Terminal Island Treatment Plant. Water Environ. Res. 74 (5) 494-507. https://doi.org/10.2175/106143002X140297

KEPP U and SOLHEIM OE (2000) Thermo dynamical assessment of the digestion process. $5^{\text {th }}$ European Biosolids and Organic Residuals Conference, November 2000, Wakefield, UK.

KOR-BICAKCI G and ESKICIOGLU C (2019) Recent developments on thermal municipal sludge pretreatment technologies for enhanced anaerobic digestion. Renew. Sustainable Energ. Rev. 110 423-443. https://doi.org/10.1016/j.rser.2019.05.002

KRUGEL S, HAMEL K and AHRING BK (2002) North America's first new temperature phased anaerobic digestion system - a successful start-up at the Western Lake Superior Sanitary District (WLSSD). In: Proc. Water Environment Federation, Residuals and Biosolids Management 19 452-470. https://doi.org/10.2175/193864702785302663

LANCASTER R (2015) Thermal hydrolysis at Davyhulme WWTW one year on. Proceedings of WEF Residuals and Biosolids 2015. Water and Environment Federation, Washington DC.

LLORET E, PASTOR L, PRADAS P and PASCUAL JA (2013) Semi fullscale thermophilic anaerobic digestion (TAnD) for advanced treatment of sewage sludge: Stabilization process and pathogen reduction. Chem. Eng. J. 232 42-50. https://doi.org/10.1016/j.cej.2013.07.062
MARTINEZ EJ, GIL MV, FERNANDEZ C, ROSAS JG and GOMEZ $\mathrm{X}$ (2016) Anaerobic codigestion of sludge: addition of butcher's fat waste as a cosubstrate for increasing biogas production. PloS One 11 (4) e0153139. https://doi.org/10.1371/journal.pone.0153139

MEHDIZADEH SD, ESKICIOGLU C, BOBOWSKI J and JOHNSON $\mathrm{T}$ (2013) Conductive heating and microwave hydrolysis under identical heating profiles for advanced anaerobic digestion of municipal sludge. Water Res. 47 5040-5051. https://doi.org/10.1016/j. watres.2013.05.055

MININNI G, LAERA G, BERTANZA G, CANATO M and SBRILLI A (2015) Mass and energy balances of sludge processing in reference and upgraded wastewater treatment plants. Environ. Sci. Pollut. Res. 22 7203-7215. https://doi.org/10.1007/s11356-014-4013-2

MOTTET A, STEYER JP, DÉLÉRIS S, VEDRENNE F, CHAUZY J and CARRÈRE H (2009) Kinetics of thermophilic batch anaerobic digestion of thermal hydrolysed waste activated sludge. Biochem. Eng. J. 46 169-175. https://doi.org/10.1016/j.bej.2009.05.003

MULLER JA (2001) Prospects and problems of sludge pre-treatment processes. Water Sci. Technol. 44 121-128. https://doi.org/10.2166/ wst. 2001.0598

NEYENS E and BAEYENS J (2003) A review of thermal sludge pretreatment processes to improve dewaterability. J. Hazardous Mater. B98 51-67. https://doi.org/10.1016/S0304-3894(02)00320-5

OOSTERHUIS M, RINGOOT D, HENDRKS A and ROELEVELD P (2014) Thermal hydrolysis of waste activated sludge at Hengelo wastewater treatment plant, The Netherlands. Water Sci. Technol. 70 (1) 1-7. https://doi.org/10.2166/wst.2014.107

PILLI S, YAN S, TYAGI RD and SURAMPALLI RY (2015) Thermal pretreatment of sewage sludge to enhance anaerobic digestion: A review. Crit. Rev. Environ. Sci. Technol. 45 669-702. https://doi.org/ 10.1080/10643389.2013.876527

PINTO N, CARVALHO A, PACHECO J and DUARTE E (2016) Study of different ratios of primary and waste activated sludges to enhance the methane yield. Water Environ. J. 30 203-210. https://doi. org/10.1111/wej.12188

RUBIO-LOZA LA and NOYOLA A (2010) Two-phase (acidogenicmethanogenic) anaerobic thermophilic/mesophilic digestion system for producing Class A biosolids from municipal sludge. Bioresour. Technol. 101 576-585. https://doi.org/10.1016/j.biortech.2009.08.066

SHAO YJ, KIM HS, OH S, IRANPOUR R and JENKINS D (2002) Fullscale sequencing batch thermophilic anaerobic sludge digestion to meet EPA class A biosolids requirements. Proceedings of the Water Environment Federation, WEFTEC 2002, Session 21-30, 573-591. https://doi.org/10.2175/193864702784247765

TCHOBANOGLOUS G, BURTON FL, STENSEL HD (2004) Wastewater Engineering: Treatment and Reuse. McGraw-Hill, Singapore.

TOMEI MC, BERTANZA G, CANATO M, HEIMERSSON S, LAERA G and SVANSTROM M (2016) Techno-economic and environmental assessment of upgrading alternatives for sludge stabilization in municipal wastewater treatment plants. J. Clean. Prod. 112 31063115. https://doi.org/10.1016/j.jclepro.2015.10.017

WINDAU T (2004) Temperature-phased anaerobic digester startup. Proceedings of the Water Environment Federation, Residuals and Biosolids Management 13 29-41. https://doi. org/10.2175/193864704784343351

WINTER P and PEARCE P (2010) Parallel digestion of secondary and primary sludge. In: Horan, N.J. (Ed.), Proceedings of the 15th European Biosolids and Organic Resources Conference, November, Aqua Enviro, Leeds.

WOUTER G and VERSTRAETE W (1997) Anaerobic digestion of primary sludge from chemical pre-precipitation. Water Sci. Technol. 36 (6-7) 357-365. https://doi.org/10.2166/wst.1997.0611

YAN Y, CHEN H, XU W, HE Q and ZHOU Q (2013) Enhancement of biochemical methane potential from excess sludge with low organic content by mild thermal pretreatment. Biochem. Eng. J. 70 127-134. https://doi.org/10.1016/j.bej.2012.10.011

ZIELS RM, KARLSSON A, BECK DA, EJLERTSSON J, YEKTA SS BJORN A, STENSEL HD and SVENSSON BH (2016) Microbial community adaptation influences long-chain fatty acid conversion during anaerobic codigestion of fats, oils, and grease with municipal sludge. Water Res. 103 372-382. https://doi.org/10.1016/j. watres.2016.07.043 